\title{
Social Skills and Psychological Disorders: Converging and Criterion-Related Validity for YSR and IHSA-Del-Prette in Adolescents at Risk*
}

\author{
Habilidades sociales y trastornos psicológicos: validez convergente y \\ de criterio para YSR e IHSA-Del-Prette en Adolescentes en riesgo
}

Recibido: septiembre 18 de 2010 | Revisado: junio 11 de 2011 | Aceptado: diciembre 12 de 2011

\author{
Zilda Aparecida Pereira Del Prette ** \\ Universidade Federal de São Carlos, Brasil \\ MARINA MONZANi DA ROCHA \\ Edwiges Ferreira de MATOS Silvares \\ Universidade de São Paulo, Brasil \\ Almir Del Prette \\ Universidade Federal de São Carlos
}

\section{A B S T R A C T}

This study evaluated indexes of converging and criterion-related validity for the Social Skills Inventory for Adolescents (IHSA-Del-Prette) and the Youth Self-Report (YSR) in two samples: one referring to clinical service (CLIN), with 28 adolescents (64.3\% boys), 11 through 17 years old $(M=13.75 ; S D=1.74)$, and the other referring to a psycho-educational program $(\mathrm{PME}=46.2 \%)$, mainly composed of boys $(91.7 \%)$ aged 13 through $17(M=15.33 ; S D=1.47)$. Both samples completed the two inventories. Results showed a high incidence of psychological disorders in both samples (between $4 \%$ and $79 \%$ in the borderline or clinical range on YSR scales) and accentuated deficits in the general and subscale scores of IHSA-Del-Prette, especially on the frequency scale ( $25 \%$ to $58 \%$ ). The correlations between the instruments in the two groups supported criterion-related and converging validity. Some issues concerning the differences between the samples and about the construct of social competence, underlying these inventories, are discussed. Key words authors:

Para citar este artículo: Del Prette, Z. A. P., Rocha, M. M., Silvares, E. M., \& Del Prette, A. (2012). Social skills and psychological disorders: Converging and criterion-related validity for YSR and IHSA-Del-Prette in adolescents at risk. Universitas Psychologica, 11(3), 941-955.

* The following students of the Undergraduate Psychology Course of USP and UFSCar (Group: 201235C, 2008) assisted in collecting the data: Alessandra M. F. Moscaritolo, Domitila Gonzaga, Nayá Custodio, Carolina Parada, Flavia Evangelista and Gabriela Lima. The authors would like to thank the team of the Psycho-Educational Measurements Program of São Carlos for their assistance, in particular psychologist Renata Moura, and the Adolescents Center of Services and Support (CAAA - UNIFESP), especially Dr. Teresa Schoen-Ferreira, who also aided in collecting the data. Grant from CNPq and FAPESP.

** Professora Titular do Departamento de Psicologia da Universidade Federal de São Carlos (http://www. rihs.ufscar.br).E-mail: zdprette@ufscar.br Social Skills, Psychological Disorders, Criterion-Related Validity, YSR, IHSA-Del-Prette. Key words plus:

Psychological tests, Psychometry, Quantitative Research.

\section{RESUMEN}

Este estudio evaluó los índices de validez convergente y de criterio para el Social Skills Inventory for Adolescents (IHSA-Del-Prette) y el Youth Self-Report (YSR) en dos muestras: una que fue referida al servicio clínico (CLIN), con 28 adolescentes (64.3\% hombres), entre 11 a 17 años de edad $(\mathrm{M}=13.75 ; \mathrm{DE}=1.74)$, y otra que fue referida a un programa psico-educativo (PME $=46.2 \%$ ), principalmente compuesto de hombres jóvenes (91.7\%) entre los 13 y los 17 años de edad $(M=15.33 ; D E=1.47)$. Las dos muestras completaron los dos inventarios. Los resultados mostraron una alta incidencia de desórdenes psicológicos en ambas muestras (entre 4\% y 79\% en el límite o rango clínico en las escalas YSR) y déficits acentuados en las puntuaciones generales y subescala de IHSA-Del-Prette, especialmente en la escala de frecuencia ( $25 \%$ a $58 \%)$. Las correlaciones entre los instrumentos en los dos grupos apoyaron la validez de criterio y la convergente. Se discuten algunos aspectos que subyacen a estos inventarios relacionados con las diferencias entre las muestras y con respecto al constructo de la competencia social. 
Palabras clave autores:

Habilidades sociales, desórdenes psicológicos, validez de criterio, YSR, IHSA-Del-Prette.

Palabras clave descriptores:

Pruebas psicológicas, psicometría, investigación cuantitativa.

Many problems are experienced by youth in contemporary society. Among the most recurrent, one can emphasize abuse of alcohol and other substances such as marijuana and tobacco (Coutinho, Araújo, \& Gontiès, 2004; Goldberg-Lillehoj, Spoth, \& Trudeau, 2005; Iglesias, Ramos, Rivera, \& Moreno, 2010), delinquency or becoming involved in groups of thieves or traffickers (Abramovay, Waiselfistz, Andrade, \& Rua, 2004; Silva, 2004), sexual commerce and sexually transmitted diseases (CerqueiraSantos, Morais, Moura, \& Koller, 2008; Libório, 2005), violence against peers or bullying (Espelage \& Swearer, 2003; Pavarino, Del Prette, \& Del Prette, 2005; Williams, 2004), and acts of vandalism with aggressive attacks on minority groups (Espelage \& Swearer, 2003; Guimarães \& Faria, 2007; Murta, Del Prette, Nunes, \& Del Prette, 2007). Among the problems which have most attracted the attention of researchers on human behavior in several parts of the world is that of violence.

Related to the problems that affect youths and which are presented, sometimes as causes, sometimes as consequences, or as both, are the so-called psychological disorders, many of which are clearly associated with behavioral problems that start in childhood (Bolsoni-Silva \& Del Prette, 2003; Del Prette \& Del Prette, 2002, 2005; Marturano, Linhares, \& Loureiro, 2004; Patterson \& Yoerger, 2002) and the deployments which can characterize a risk trajectory (Abaid, Dell'aglio, \& Koller, 2010; Del Prette \& Del Prette, 2005; Walker \& Severson, 2002). The etiology of psychological disorders in adolescence is linked to a set of risk and protection factors which act together, characterizing the vulnerability and resilience to different psychopathologies (Abaid et al., 2010; Barra-Almagia, 2009; Marturano et al., 2004) and, not uncommonly, to the incidence of co-morbidity among them (Cuijpers, Van Straten, \& Warmerdam, 2007; Rockhill, Vander Stoep, McCauley \& Katon, 2009). Among protective factors, the studies have identified, among other things, good academic performance, involvement in extracurricular activities, healthy parental educational practices, positive self-esteem and having at least one or two friends (Jacobs, Vermon, \& Ecles, 2004; Mahoney, Caims \& Farmer, 2003; Nightingale \& Fischoff, 2002; Walker \& Severson, 2002).

A good repertoire of social skills has also been included among protective factors against psychological disorders and problems (Campos, Del Prette \& Del Prette, 2000; Del Prette \& Del Prette, 2002, 2005; Gresham, 2009; Walker \& Severson, 2002). This repertoire is important because it also favors the other protective factors, for example, participating in extracurricular activities, improving self-esteem, making friends, and even scholastic achievement. On the other hand, deficits in social skills are acknowledged to be correlated with a wide range of psychological disorders and different types of psycho-social maladjustment (Del Prette \& Del Prette, 2002, 2005, 2006; Gresham, 2009; Walker \& Severson, 2002). They can constitute, as per Del Prette and Del Prette (2005, p. 19), "symptom or part of the effects of several disorders, in the first case, being able to be regarded as warning signs for possible problems in later development cycles". As they concern a learned repertoire, deficiencies in social skills can be overcome by means of preventive and remedial programs (Elliott \& Gresham, 2008; Gresham, 2009; Gresham, Cook, Crews \& Kern, 2004). Adolescents receiving clinical attention or attending psycho-educational programs can have personal characteristics and a repertoire different from that of the youthful population in general, requiring special attention from health professionals, researchers and entities committed to the well-being and quality of life of this population.

Planning efficient programs to attend youths depends upon a good evaluation of the personal resources and problems of this clientele and, therefore, on an arsenal of valid and reliable instruments. Besides construct-validity, two other important indicators of the psychometric quality of instruments are the converging and criterion-related validity. According to authors in this field (e.g. Anastasi \& 
Urbina, 2000; Kamphaus \& Frick, 2002; Pasquali, 2003), converging validity is generally based upon a nomological span of empirical evidence regarding the relationship between the scores on a test and other variables, including results of other tests which measure similar or related constructs. Therefore, significant correlations are taken between these variables as indicators of converging validity. Criterion-related validity refers to evidence that the instrument differentiates people who are in fact different with respect to a determined standard criterion. Application of the instrument and checking of the criterion can be simultaneous (concurrent, concomitant validity) or the criterion can be verified in the future (predictive validity). In general, the criterion validity indicators are expressed by the proportion of positive (sensitivity) and negative (specificity) "cases" correctly identified by the instrument and by the probability of the instrument being correct in this identification (positive and negative predictive value).

Among the instruments for adolescents are the Social Skills Inventory for Adolescents ([IHSADel-Prette]; Del Prette \& Del Prette, 2009a), validated in Brazil, and the Youth Self-Report Inventory ([YSR]; Achenbach \& Rescorla, 2001), in the process of cross-cultural adaptation (Rocha, 2011). The IHSA-Del-Prette produces scores for the repertoire of self-reported social skills. A highly elaborated repertoire is expected to be associated with indicators of psychosocial adjustment and high social competence, whereas a deficient repertoire can be associated with personal risk conditions for the individual. The YSR produces indicators about many different symptoms of psychological disorders and two indicators of adaptive resources, one designated as Positive Aspects and the other as Competences. Both instruments produce indicators of Social Competence. However, considering the construct validity, it is important to observe the conceptual differences that form the basis for the construction of these two instruments.

IHSA-Del-Prette's items are based upon the concepts of the field of social skills and social competence. Social competence is defined as a qualification of interpersonal performance in accordance with the instrumental and ethical functionality of said performance (Del Prette \& Del Prette, 2001, 2005). The competences score of the YSR, based on the field of clinical psychopathology, is derived empirically from items which assess engagement in activities, social relationships and academic achievement (Achenbach \& Rescorla, 2001), regardless of the quality of the specific performance presented. It is reasonable to expect a correlation between the social skills scores of the IHSA-Del-Prette and the competences scores of the YSR: certainly an elaborate repertoire of social skills and a high degree of social competence are favorable conditions for engaging in social activities, such as those assessed by the YSR. However, given the lack of studies about these two constructs, this relationship constitutes an empirical issue that has yet to be investigated.

Considering what it set forth, the present study with two samples of adolescents (both receiving psychological and psycho-educational attention) aimed to check: (a) the concurrent criterionrelated validity of the IHSA-Del-Prette and YSR, in terms of their sensitivity in producing critical scores when compared to the normative reference scores; (b) the converging validity between the scores produced by these two instruments.

\section{Method}

\section{Participants}

Data were collected with two samples. The CLIN sample, with 28 adolescents, who were between 11 and 17 years of age $(M=13.75 ; S D=1.74), 18$ males and 10 females who were referred for treatment in two psychology school services of São Paulo City, Brazil, due to several kinds of problems such as anxiety, aggressiveness, and learning-disability. The PEM sample, 24 adolescents, aged between 13 and 17 years of age $(M=15.33$; $S D=1.47), 22$ males and 2 females who were fulfilling psycho-educational measures, in a program run by the municipality of São Carlos, Brazil and intended for adolescents on parole, under the guardianship of a juvenile court, and aimed at re-socialization, with psychological, pedagogi- 
cal and occupational therapy. Both samples were similar in racial ethnic background (most white or mulatto) as well as in socioeconomic level because, according to the Brazil Criterion ${ }^{1}$, most of them were in classes B2 and C (23.1\% and 57.7\%, respectively).

\section{Instruments}

\section{Social Skills Inventory for Adolescents ([IHSA-Del-Prette]; de Del Prette EO Del Prette, 2009a).}

This is a self-report instrument for assessing social skills of adolescents, and referred to standard norms in percentiles. The manual (Del Prette \& Del Prette, 2009a) presents indexes of satisfactory instrument validity (item analysis, internal consistency, factorial structure) and reliability (test-retest correlations) based on what was recommended by the Brazilian Federal Psychology Council. It is composed of 38 items which handle relationship skills with different interlocutors (affective-sexual partner, parents and siblings, colleagues, friends, people in authority, strangers, or not specified) that are required in a public (school, work, leisure, consumption), private (family and intimate), or unspecified context. In each item, the adolescent is requested to estimate: (a) his/her difficulty in presenting the reaction indicated in the item; (b) the frequency with which he/she presents that reaction. The answers are marked on a Likert-type scale, producing a general score of difficulty and one of frequency. Moreover, it produces scores on six subscales: F1-Empathy, F2-Self-control, F3Civility, F4-Assertiveness, F5-Affective Approach and F6-Social Adroitness. Annex A presents the range of each score, one example of each, and the internal consistency (Alpha Coefficient) for each sample and for the total sample.

1 The Brazil Criterion Questionnaire classifies the respondent, based on durable consumer goods and schooling level, in one of five classes: three of greater acquisitive power, subdivided into seven levels (A1, A2, B2, B3, C1 and C2, D and E). See: http:// www.abep.org/codigosguias/Criterio_Brasil_2008.pdf
Youth Self-Report ([YSR];

Achenbach Eु Rescorla, 2001).

This instrument is developed for youths from 11 to 18 years of age to assess their own behavior, is widely used internationally (Rescorla et al., 2007a), and is currently being validated in Brazil with good preliminary results indicating internal consistency and discriminating capacity of scales and items (Rocha, 2011). The report is composed of two parts, the first is intended to assess Competences (in Activities, Social and Academic Performance), and the second, which is intended to assess Behavioral Problems, is divided into eight scales-syndromes derived from the factorial analyses of data with the North American population (Achenbach \& Rescorla, 2001) and ratified in confirming factorial analyses in Brazil (Rocha, 2011): Anxious/Depressed, Withdrawn/ Depressed, Somatic Complaints, Social Problems, Thought Problems, Attention Problems, RuleBreaking Behavior, and Aggressive Behavior. The behavioral problem scales are united in three scales: Internalizing Problems, which encompasses the first three scales; Externalizing Problems, which encompasses the last two; and Total Problems, which encompasses all the items of problems analyzed by the questionnaire. The YSR also has 14 items intended to assess socially-desirable behavior grouped on the Positive Aspects scale. The scores obtained by the adolescent on each of the scales are calculated by adding up the points of each item and converting them into percentiles which define the normal, borderline and clinical ranges. In the present study, the borderline range was grouped with the clinical range, following the suggestion of Achenbach and Rescorla (2001), to avoid false negatives.

\section{Procedure}

The study with the adolescents of the program of psycho-educational measures (PEM) and those forwarded for psychological treatment (CLIN) are part of two large projects, approved, respectively by the Ethics Councils of the authors' institution 
TABLE 1

Percentage of respondents positioned in percentiles indicating deficient (1), median (2) and elaborated (3) social skills repertoire*, as identified in the assessment by means of the IHSA-Del-Prette

\begin{tabular}{|c|c|c|c|c|c|c|c|}
\hline & \multirow{2}{*}{ INDICATOR AND SCORES } & \multicolumn{3}{|c|}{ PEM $(N=24)$} & \multicolumn{3}{|c|}{ CLIN $(N=28)$} \\
\hline & & 1 & 2 & 3 & 1 & 2 & 3 \\
\hline \multirow{7}{*}{ 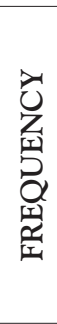 } & General Score & 0.58 & 0.17 & 0.25 & 0.36 & 0.43 & 0.21 \\
\hline & F1 - Empathy & 0.46 & 0.33 & 0.21 & 0.39 & 0.39 & 0.21 \\
\hline & F2 - Self-control & 0.46 & 0.42 & 0.13 & 0.57 & 0.25 & 0.18 \\
\hline & F3 - Civility & 0.25 & 0.54 & 0.21 & 0.32 & 0.32 & 0.36 \\
\hline & F4 - Assertiveness & 0.38 & 0.33 & 0.29 & 0.39 & 0.36 & 0.25 \\
\hline & F5 - Affective Approach & 0.25 & 0.46 & 0.29 & 0.43 & 0.39 & 0.18 \\
\hline & F6 - Social Adroitness & 0.58 & 0.38 & 0.04 & 0.61 & 0.18 & 0.21 \\
\hline \multirow{7}{*}{ 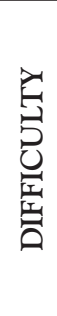 } & General Score & 0.25 & 0.33 & 0.42 & 0.54 & 0.32 & 0.14 \\
\hline & D1 - Empathy & 0.17 & 0.38 & 0.46 & 0.54 & 0.25 & 0.21 \\
\hline & D2-Self-control & 0.21 & 0.54 & 0.25 & 0.39 & 0.50 & 0.11 \\
\hline & D3 - Civility & 0.21 & 0.42 & 0.38 & 0.46 & 0.18 & 0.36 \\
\hline & D4 - Assertiveness & 0.25 & 0.46 & 0.29 & 0.46 & 0.43 & 0.11 \\
\hline & D5 - Affective Approach & 0.17 & 0.33 & 0.50 & 0.57 & 0.25 & 0.18 \\
\hline & D6 - Social Adroitness & 0.17 & 0.50 & 0.33 & 0.39 & 0.36 & 0.25 \\
\hline
\end{tabular}

$* 1$ = Deficient (0-25 for frequency; 76-100 for difficulty); 2 = Median (26-75) and 3 = Elaborated (76-100 for frequency; $0-25$ for difficulty)

Source: own work.

(Protocol CEP-UFSCar \# 206/2005 and Protocol CEPH-IP of 04/23/07). The standards of the legislation in force about ethics in research involving human beings were followed, especially regarding the Term of Free and Clarified Consent, signed by the parents authorizing the participation of the adolescents in the study. The two instruments were answered by the youths, in sessions conducted by psychologists or by research assistants duly prepared for this task, and which lasted an average of 70 minutes.

\section{Data treatment}

The results of the IHSA-Del-Prette converted into scores were first submitted to reliability analysis (Alpha Coefficient). As shown in Annex A, most of the internal consistency indexes were satisfactory or acceptable, with only five (out of 29 indexes) proving unreliable in the PEM sample and two (out of 29) in the CLIN sample. For assessing sensitivity, concerning the start indicator of criterion validity, the scores were converted into percentiles ${ }^{2}$ and compared with the measurements and cut-off points of the normative reference. In the case of the YSR, the cut-off points for the American standard were used, since the Brazilian standards are still being constructed. In any case, in a study that compared ratings of emotional and behavioral problems of youths from 24 societies using the YSR, 17 countries scored within one standard deviation from the Total Problems overall mean, indicating considerable multicultural consistency (Rescorla et al., 2007a). In order to check the converging validity, correlation analyses were performed between the scores produced by the two instruments, separately for each sample. Finally, correlation between all

2 The IHSA-Del-Prette scores were converted into percentiles, as per the computerized determination program and instructions manual (Del Prette \& Del Prette, 2009a). The answers to the YSR were analyzed using the Assessment Data Manager program developed by the Achenbach System of Empirically Based Assessment (ASEBA) team, for calculating the scores and percentiles (Achenbach System of Empirically Based Assessment, 2006). 
TABLE 2

Descriptive and percentage data of clinical cases identified in the assessment by means of the YSR in the study sample

\begin{tabular}{lccc}
\hline \multicolumn{1}{c}{ Scales factors } & Borderline/Clinical Range & PEM (N=24) & CLIN (N=28) \\
\hline Anxious/Depressed & $>93$ & 0.42 & 0.36 \\
Withdrawn/Depressed & $>93$ & 0.42 & 0.39 \\
Somatic Complaints & $>93$ & 0.29 & 0.04 \\
Social Problems & $>93$ & 0.29 & 0.32 \\
Thought Problems & $>93$ & 0.38 & 0.14 \\
Attention Problems & $>93$ & 0.25 & 0.29 \\
Rule-Breaking Behavior & $>93$ & 0.54 & 0.14 \\
Aggressive Behavior & $>93$ & 0.46 & 0.39 \\
Internalizing Problems & $>84$ & 0.63 & 0.46 \\
Externalizing Problems & $>84$ & 0.79 & 0.54 \\
Total Problems & $>84$ & 0.63 & 0.54 \\
Activities & $<7$ & 0.42 & 0.18 \\
Social & $<7$ & 0.71 & 0.68 \\
Total Competences & $<16$ & 0.40 & 0.57 \\
Positive Qualities & $<7$ & 0.04 & 0 \\
\hline
\end{tabular}

Source: own work.

scores of both instruments was done, separately for each sample.

\section{Results}

Initially, the criterion-validity data of each one of the instruments is presented, which allowed a characterization of the sample of this study considering the normative standards. Then, the converging validity data between the two instruments is presented.

\section{Characterization of the sample in the scores of the IHSA-Del-Prette}

The results obtained in the assessment by means of the IHSA-Del-Prette, for the indicators of frequency and difficulty in displaying social skills are presented in Table 1 in percentages of subjects by range of percentiles, considering their position in relation to the normative sample taken as the criterion (Del Prette \& Del Prette, 2009).

As per Table 1, considering the frequency, the percentage of PEM participants with indication for receiving programs of social-skills training was rather high in the General Score and in the skills of Self-Control, Empathy, and Social Adroitness, with approximately half or more of the sample having a deficient repertoire. However, Assertiveness was also a cause for worry with a percentage higher than the normative percentiles distribution (25\%), even considering the normative number of respondents with elaborated repertoire (76-100). Concerning the difficulty of performing social skills, the PEM sample did not present deficits.

In the CLIN sample, about one-third of the participants presented deficits in all the frequency scores, with about half of them presenting problems in Self-Control, Affective Approach and Social Adroitness. Correspondingly, more than half of them reported difficulty in performing social skills for General Score and for subscales of Empathy and Affective Approach, with percentage higher than normative for the other subscales as well.

\section{Characterization of the Sample} in the YSR Scores

The results produced by adolescents' self-report on the YSR were compared with the normative data of cut-off points, as shown in Table 2. 
Assessing the number of cases which achieved the clinical range of the YSR, it can be seen in the CLIN sample that more than half the adolescents had scores in the clinical range for Total Competences, indicating that they generally engage in fewer social relationships and activities and achieve academic performance below that expected for their age range. In the case of this sample, the problems seem to be with respect to social relationships, since $68 \%$ of the adolescents reported engaging in fewer social relationships than expected. For the PEM sample, 40\% achieved clinical scores for Total Competences, while most of them reported social problems (70\%) and $42 \%$ also reported engaging in fewer activities than expected.

For the behavior-problem scales, the percentage of youths from the CLIN sample who reported more problems than expected for the Total Problems scale was high, with more than half the sample achieving clinical scores. The CLIN sample also reported several Externalizing Problems, with 54\% achieving clinical scores, and Internalizing Problems, with $46 \%$ achieving clinical scores. On the syndrome scales, the number of youths from the CLIN sample who reported more problems than expected (clinical cases) varied from $4 \%$ for Somatic Complaints, to 39\% for Withdrawn/ Depressed and Aggressive Behavior. Similar results were found for the PEM sample, with $63 \%$ of the youths achieving the clinical cut-off for Total Problems. Externalizing Problems was the most frequent problem, with 79\% achieving higher scores than expected. Considering the syndrome scales, the one with the least number of adolescents from the PEM sample with clinical scores was Attention Problems, but even for this area, $25 \%$ of the PEM sample reported more problems than expected. Rule-Breaking Behavior was the scale on which most PEM youths achieved clinical scores $(54 \%)$.

It can be noted that, in the scores of sociallydesirable behavior, both samples are similar to youths from the normative population (American), and that only one participant from the PEM sample attained scores equivalent to the deficient, clinical percentile for the Positive Aspects scale.

Correlations between the Scores of the IHSA-Del-Prette and the YSR

Considering the correlation between the scores of the YSR and the IHSA-Del-Prette, the data relating to the frequency indicators of social skills is presented in Tables 3 and 4.

Data indicate that all significant correlations occurred in the expected direction as per the relevant literature, although some, expected up to a certain point, did not attain a significant level, possibly due to the reduced size of each sample. Atypical results occurred only in two cases of correlations between scores with no internal consistency (PEM sample, Social with F4 and D3), although other not consistent indicator also produced the expected correlations (CLIN sample, Social with Frequency of Total Social Skills).

In general, for both samples YSR problems indicators were negatively correlated with frequency indicators of social skills and positively correlated with difficulty indicators of social skills (except in one case of no internal consistency scores). Specifically, both samples negatively correlated frequency scores of Total Social Skills with Withdrawn/Depressed and positively correlated difficulty scores of Total Social Skills with Withdrawn/Depressed, Attention Problems and Internalizing Problems; both also correlated Empathy (D1) with Attention Problems. The remaining correlations were not common to both samples, with CLIN adolescents presenting more correlations between YSR scores and frequency indicators of social skills, while PEM presented more correlations between YSR scores and difficulty indicators of social skills.

Additionally, the CLIN sample negatively correlated frequency scores of Civility (F3) with Withdrawn/Depressed, Social Problems, and Attention Problems, and Assertiveness (F4) with Attention Problems. Positive correlations were established between frequency of Total Social Skills and all YSR competence scales (Activities, Social, and Total Competences). While Activities seems to be correlated with Self-Control (F2), Social Com- 


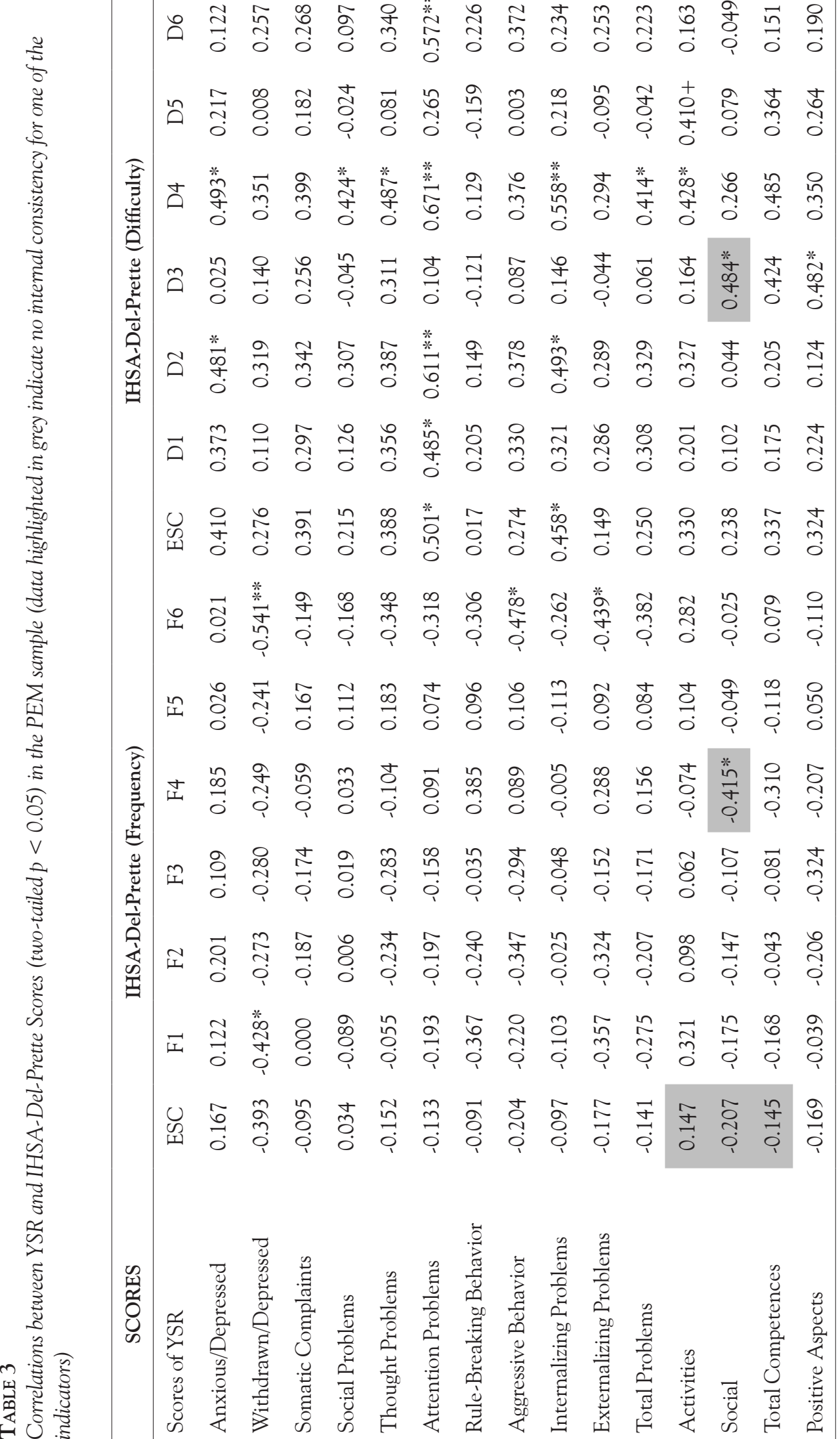




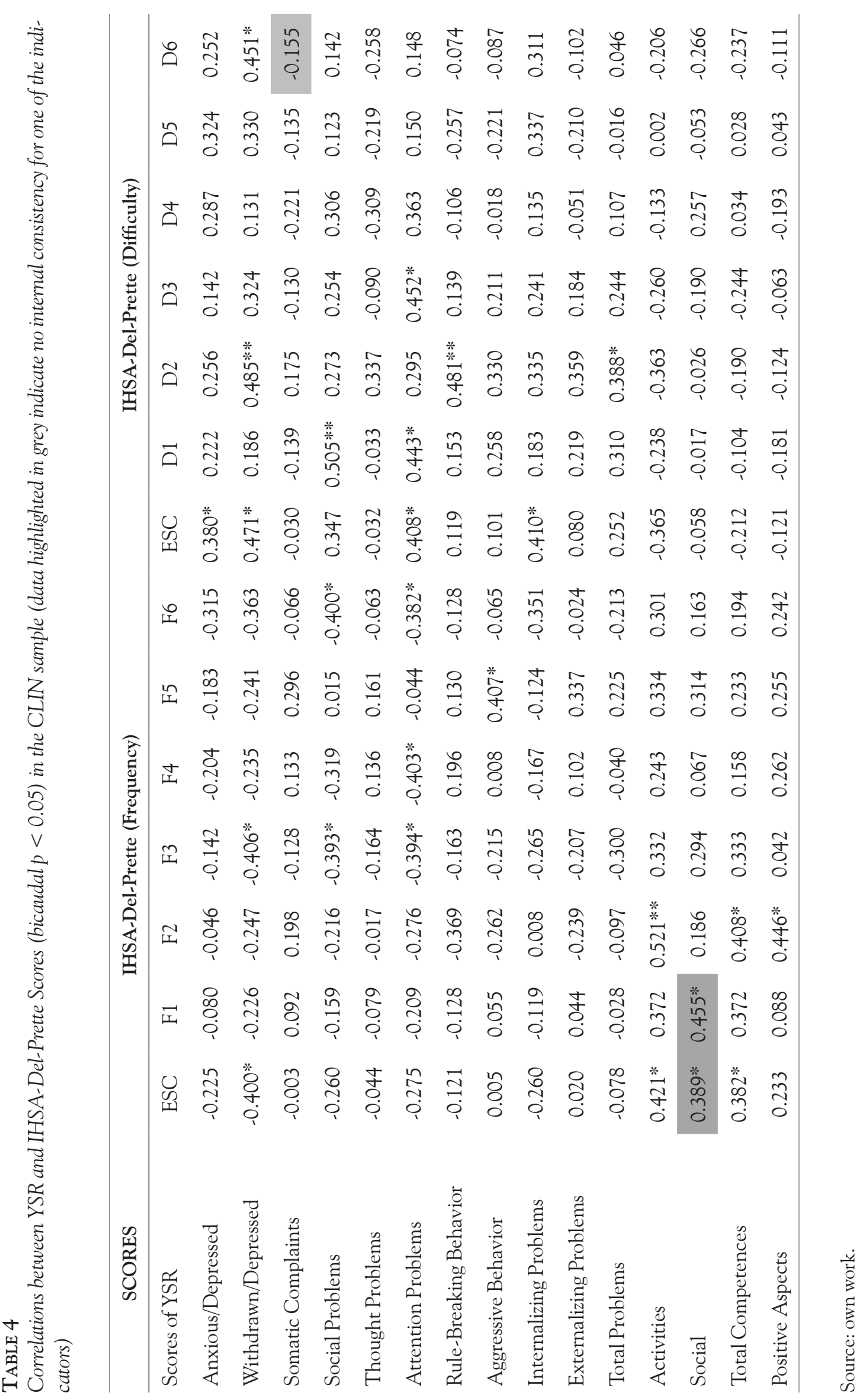


petence in the YSR seems to be correlated with Empathy (F1). Moreover, positive correlations were found between difficulty indicators of social skills and YSR problems scales: Anxious/Depressed and Total Social Skill, Withdrawn/Depressed and SelfControl (D2) and Social Adroitness (D6), Social Problems and Empathy (D1), Attention Problems and Civility (D3), and Rule Breaking Behavior and Self-Control (D2).

Regarding the PEM sample, frequency of Social Adroitness (F6) negatively correlated with Withdrawn/Depressed, Aggressive Behavior, and Externalizing Problems. Positive correlations were found within difficulty indicators of social skills and YSR scores, especially for Assertiveness (D4), which correlated positively with Anxious/Depressed, Social Problems, Attention Problems, Internalizing Problems and Total Problems.

Although it was not the major goal of this research, it is also worth noting that all correlations between difficulty and frequency indicators of social skills were negative for both samples, which is consistent with the normative sample of the IHSA-DelPrette (Del Prette \& Del Prette, 2009a).

\section{Discussion}

The results indicate converging validity between several parameters of the YSR and the IHSA-DelPrette. Moreover, they provide preliminary indicators of criterion validity for both instruments, since the results of the assessment confirmed the sample's predominant clinical condition in several psychological disorders and its deficiency in the repertoire of social skills. In other words, the two instruments were capable of describing each sample related to the criterion of normative distribution of these instruments scores.

Concerning the incidence of borderline and clinical cases for psychological disorders in the YSR, a high frequency of Internalizing and Externalizing Problems was found. Moreover, more than half the youths achieved borderline and clinical scores on the Total Problems Scale, which encompasses all the difficulties listed. This result, besides being expected, due to the type of population assessed (one sample referred for psychological treatment and the other undergoing a program of psychoeducational measurements), is similar to that found in the preliminary validation study of the YSR in Brazil (Rocha, 2011), in which $61.5 \%$ of the youths remitted to mental health services achieved the clinical range using the American cut-offs. However, it is worth pointing out the higher percentage of adolescents identified with Externalizing Problems in the present study (79\% in the PEM sample and $54 \%$ in the CLIN sample), which is probably also due to the male predominance, as referred to in several studies (Achenbach \& Rescorla, 2001; Costello, Mustillo, Erkanli, Keeler \& Angold, 2003; Rescorla et al., 2007a).

Regarding the repertoire of social skills, the low frequency scores in the skills of Self-Control (F2) and Social Adroitness (F6) in both samples are also coherent with the literature which relates the deficiency in social skills to different psychosocial disorders (Del Prette \& Del Prette, 2001, 2002). In the PEM sample, the low scores in the indicators of difficulty of the IHSA-Del-Prette suggest that the deficiency identified is mainly in performance (Del Prette \& Del Prette, 2005, 2009a), indicating the crucial role played by environmental contingencies in the motivation and maintenance of adaptive behavior for these adolescents. In the case of the CLIN sample, the high scores of difficulty in performing social skills suggest anxiety and other psychological problems associated with social relationships, probably more easily perceived by the adolescents remitted to receive attention.

In relation to the converging validity, the positive correlation between disorders (Rule-Breaking Behavior) and the difficulty in the skills of Affective Approach (F5) found in the CLIN sample suggests that the antisocial behavior of the adolescents can also have an impact upon the field of affective relationships, thereby restricting the possible protective factors even further. It is interesting to note that, even with low scores in self-report of difficulty in performing social skills, the PEM sample presented more correlations between difficulty indicators and psychological problems than the CLIN sample. It is reasonable to assume that a portion of these adoles- 
cents experiment high anxiety and other kinds of psychological disturbances related to transgression.

The converging validity between the two instruments occurred in the expected direction, i.e., a positive correlation between the YSR competences scales and the frequency of social skills of the IHSADel-Prette, as well as a negative correlation with the scores in difficulty in social skills. Nevertheless, such correlations were only significant for the CLIN sample. This datum suggests the importance of social activities engagement as a condition for perfecting the repertoire of social skills. However, the lack of correlations between the results of the IHSA-Del-Prette and the Social and Total of Competences scales for the PEM sample implies the need for further studies with these adolescents in order to refine its psychometric properties (internal consistency). In the specific case of Social Competence, the difference should be pointed out between the two instruments in the conception of this construct, as referred to in the introduction to this paper. On the other hand, one cannot discard the restriction imposed by the size of both samples.

The results of the analysis of the correlation between the scores of the two instruments indicate a general expected direction in accordance with the relevant literature: the social skills constitute adaptive and substituting behavior of many psychological disorders and problems (Gresham, 2009). In the specific case of adolescents at risk, like those in both samples, it was found that, on the whole, the adolescents with more behavioral problems tended to report less frequency and greater difficulty in social skills. This is quite explicit when analyzing the data from the Withdrawn/Depressed problems as well as the difficulty in performing a specific class of social skills, i.e., Assertiveness (D4). This relationship would even be expected given the nature of these problems which could be grouped with the construct of affective blunting (Carneiro \& Yoshida, 2009), whereas social competence involves, as a general rule, greater expressiveness and extroversion (Bartholomeu, Nunes \& Machado, 2008; Bueno, Oliveira \& Oliveira, 2001).

The characterization data of the adolescents undergoing psycho-educational measurements and re- ferred for clinical psychological treatment produced by this study could also be exploited in programs or policies for preventing the incidence of disorders such as those found here. Many programs have been developed for this purpose (Botvin, 2000; Del Prette \& Del Prette, 2003; Del Prette \& Del Prette, 2006; Silveira, Silvares \& Marton, 2003), with indicators of social validity and effectiveness, in terms of acceptance by the youths.

Notwithstanding the evidence of converging and criterion-related validity of this study for the two instruments, its limitations should also be taken into account. Besides the size of both samples, the major proportion of male and lower age individuals in the PEM sample is acknowledged to be a factor that should be better assessed in future studies. Although considering the prevalence of some disorders that are more common among men than women, and the results of multicultural studies in which boys generally have more externalizing problems than girls (Rescorla et al., 2007a, 2007b), studies with larger and more balanced samples in terms of sex and age could ensure greater generality in their findings, and possibly identify other correlations, expected as per the relevant literature.

Another limitation to be considered refers to the importance of multimodal assessment in the case of social skills (Del Prette \& Del Prette, 2009b). As the study was based exclusively on self-report data, future investigations, with data obtained by means of other procedures and informants can be considered important, especially for planning intervention programs.

Finally, it should be acknowledged that the evidence of criterion-related validity in this study is as yet preliminary. There was only a focus upon the concurrent validity and, moreover, only the issue of the sensitivity of the two instruments in producing scores coherent with the characteristics of the two samples related to the normative reference. New studies should also look at the question of specificity, comparing a clinical and a non-clinical sample and the predictive value of the two instruments in terms of probability associated with the identification of cases of disorders and non-disorders. On the other hand, studies about predictive validity would 
be even more valuable, although acknowledged to be rarer in the associated literature and even more difficult to conduct in the case of psychological disorders.

\section{References}

Abaid, J. L. W., Dell'aglio, D. D. \& Koller, S. H. (2010). Preditores de sintomas depressivos em criangas e adolescentes institucionalizados. Universitas Psychologica, 9(1), 199-212.

Abramovay, M., Waiselfistz, J. J., Andrade, C. C. \& Rua, M. G. (2004). Gangues, galeras e chegados e rappers: Juventude, violência e cidadania nas cidades da periferia de Brasília. Rio de Janeiro: Garamond.

Achenbach System of Empirically Based Assessment. (2006). Manual for the assessment data manager program (ADM). Burlington, VT: Author.

Achenbach, T. M. \& Rescorla, L. A. (2001). Manual for the ASEBA School-Age Forms and Profiles. Burlington, VT: University of Vermont, Research Center for Children, Youths and Families.

Anastasi, A., \& Urbina, S. (2000). Testagem psicológica (Maria Adriana V. Veronese, Trad.). Porto Alegre: Artmed.

Barra-Almagia, E. (2009). Influencia del estrés y el ánimo depresivo sobre la salud adolescente: análisis concurrente y prospectivo. Universitas Psychologica, 8(1), 175-182.

Bartholomeu, D., Nunes, C. H. S. da S. \& Machado, A. A. (2008). Traços de personalidade e habilidades sociais em universitários. Psico-USF, 13(1), 41-50.

Bolsoni-Silva, A. T. \& Del Prette, A. (2003). Problemas de comportamento: Um panorama da área. Revista Brasileira de Terapia Comportamental e Cognitiva, 5(2), 91-103.

Botvin, G. J. (2000). Preventive drug abuse in the schools: Social competence enhancement approaches targeting individual-level etiologic factors. Addictive Behaviors, 25(6), 887-897.

Bueno, J. M. H., Oliveira, S. M. S. S. \& Oliveira, J. C. S. (2001). Um estudo correlacional entre habilidades sociais e traços de personalidade. Psicologia-USF, 6(1), 31-38.

Campos, T. N., Del Prette, Z. A. P. \& Del Prette, A. (2000). (Sobre)vivendo nas ruas: Habilidades soci- ais e valores de crianças e adolescentes. Psicologia: Reflexão e Crítica, 13(3), 517-527.

Carneiro, B. V. \& Yoshida, E. M. P. (2009). Alexitimia: Uma revisão do conceito. Psicologia: Teoria e Pesquisa, 25(1), 103-108.

Cerqueira-Santos, E., Morais, N. A., Moura, A. S. \& Koller, S. H. (2008). Exploração sexual comercial de crianças e adolescentes: Uma análise comparativa entre clientes e não-clientes do comércio sexual. Psicologia: Reflexão e Crítica, 21(3), 446-454.

Costello, E. J., Mustillo. S., Erkanli, A., Keeler, G. \& Angold, A. (2003). Prevalence and development of psychiatric disorders in childhood and adolescence. Archives of General Psychiatry, 60(8), 837-844.

Coutinho, M. P. L., Araújo, L. F. \& Gontiès, B. (2004). Uso da maconha e suas representações sociais: Estudo comparativo entre universitários. Psicologia em Estudo, 9(3), 469-477.

Cuijpers, P., Van Straten, A. S. \& Warmerdam, L. (2007). Behavioral activation treatments of depression: A meta-analysis. Clinical Psychology Review, 27(3), 318-326.

Del Prette, A. \& Del Prette, Z. A. P. (2001). Psicologia das Relações Interpessoais: Vivências para o trabalho em grupo. Petrópolis: Vozes.

Del Prette, Z. A. P. \& Del Prette, A. (2002). Transtornos psicológicos e habilidades sociais. In $\mathrm{H}$. J. Guilhardi, M. B. B. Madi, P. P. Queiroz, \& M. C. Scoz (Orgs.), Sobre comportamento e cognição: Contribuições para a construção da teoria do comportamento, (pp. 377-386). Santo André: ESETec.

Del Prette, A. \& Del Prette, Z. A. P. (2003). Aprendizagem socioemocional na escola e prevenção da violência: Questões conceituais e metodologia de intervenção. In A. Del Prette \& Z. A. P. Del Prette (Orgs.), Habilidades sociais, desenvolvimento e aprendizagem: Questões conceituais, avaliação e intervenção, (pp. 83-127). Campinas: Alínea.

Del Prette, Z. A. P. \& Del Prette, A. (2005). Psicologia das habilidades sociais na infância: Teoria e prática. Petrópolis: Vozes.

Del Prette, Z. A. P. \& Del Prette, A. (2006). Psicologia educacional, forense e com adolescente em risco: Prática na avaliação e promoção de habilidades sociais. Avaliação Psicológica, 5(1), 99-104. 
Del Prette, Z. A. P. \& Del Prette, A. (2009a). Inventário de Habilidades Sociais para Adolescentes (IHSA-DelPrette): Manual para aplicação, apuração e interpretação. São Paulo: Casa do Psicólogo.

Del Prette, Z. A. P. \& Del Prette, A. (2009b). Avaliação de habilidades sociais: bases conceituais, instrumentos e procedimentos. In A. Del Prette \& Z. A. P. Del Prette (Orgs.), Psicologia das habilidades sociais: Diversidade teórica e suas implicações, (pp. 187-229). Petrópolis: Vozes.

Elliott, S. N. \& Gresham, F. M. (2008). Classwide intervention program: Teachers's guide. Minneapolis, $\mathrm{MN}$ : Pearson.

Espelage, D. L. \& Swearer, S. M. (2003). Research on school bullying and victimization: What have we learned and where do we go here? School Psychology Review, 32(3), 365-383.

Goldberg-Lillehoj, C. J., Spoth, R. \& Trudeau, L. (2005). Assertiveness among young rural adolescents: Relationship to alcohol use. Journal of Child $\mathbb{E}$ Adolescent Substance Abuse, 14(3), 39-68.

Gresham, F. M. (2009). Análise do comportamento aplicada às habilidades sociais. In A. Del Prette \& Z. A. P. Del Prette (Orgs.), Psicologia das habilidades sociais: Diversidade teórica e suas implicações, (pp. 17-66). Petrópolis: Vozes.

Gresham, F. M., Cook, C. R., Crews, S. D. \& Kern, L. (2004). Social skills training for children and youth with emotional and behavioral disorders: Validity considerations and future directions. Behavioral Disorders, 30(1), 32-46.

Guimarães, S. P. \& Faria, P. H. (2007). Norma social violenta: Um estudo da representação social da violência em adolescentes. Psicologia: Reflexão e Crítica, 20(2), 188-196.

Iglesias, A. J., Ramos, P., Rivera, F. \& Moreno, C. (2010). El consumo de tabaco y alcohol en los adolescentes españoles y los programas educativos escolares de prevención de drogadependências. Revista de Psicologia da criança e do adolescente, 1(1), 13-30.

Jacobs, J. E., Vernon, M. K. \& Eccles, J. S. (2004). Relations between social self-perceptions, time use, and prosocial or problem behaviors during adolescence. Journal of Adolescent Research, 19(1), 45-62.
Kamphaus, R. W. \& Frick, P. J. (2002). Clinical assessment of child and adolescent personality and behavior. Boston, MA: Allyn \& Bacon.

Libório, R. M. C. (2005). Adolescentes em situação de prostituição: Uma análise sobre a exploração sexual comercial na sociedade contemporânea. Psicologia: Reflexão e Crítica, 18(3), 413-420.

Mahoney, J. L., Cairns, B. D. \& Farmer, T. W. (2003). Promoting interpersonal competence and educational success through extracurricular activity participation. Journal of Educational Psychology, 95(2), 409-418.

Marturano, E. M., Linhares, M. B. M. \& Loureiro, S. M. (2004). Vulnerabilidade e proteção: Indicadores na trajetória de desenvolvimento do escolar. São Paulo: FAPESP: Casa do Psicólogo.

Murta, S. G., Del Prette, A., Nunes, F. C. \& Del Prette, Z. A. P. (2007). Problemas en la adolescencia: contribuciones del entrenamiento en habilidades sociales. En M. R. Ríos-Saldaña (Org.), Manual de intervención psicológica para adolescentes: ámbito de la salud y educativo (Unidad 1, Cap. 2). Bogotá, Col: PSICOM Editores.

Nightingale, E. O., \& Fischoff, B. (2002). Adolescent risk and vulnerability: Overview. Journal of Adolescent Health, 31(1), 3-9.

Pasquali, L. (2003). Psicometria: Teoria dos testes na Psicologia e na Educação. Petrópolis: Vozes.

Patterson, G. R., \& Yoerger, K. (2002). A development model for early- and late-onset delinquency. In J. B. Reid, G. R. Patterson \& J. Snyder (Eds.), Antisocial behavior in children and adolescents. A developmental analysis and model for intervention, (pp. 147-192). Washington, DC: American Psychological Association.

Pavarino, M. G., Del Prette, A. \& Del Prette, Z. (2005). Agressividade e empatia na infância: Um estudo correlacional com pré-escolares. Interação em Psicologia, 9(2), 215-225.

Rescorla, L. A., Achenbach, T. M., Ivanova, M. Y., Dumenci, L., Almqvist, F., Bilenberg, N., et al. (2007a). Epidemiological comparison of problems and positive qualities reported by adolescents in 24 countries. Journal of Consulting and Clinical Psychology, 75(2), 351-358. 
Rescorla, L. A., Achenbach, T. M., Ivanova, M. Y., Dumenci, L., Almqvist, F., Bilenberg, N., et al. (2007b). Behavioral and emotional problems reported by parents of children ages 6 to 16 in 31 societies. Journal of Emotional and Behavioral Disorders, 15(3), 130-142.

Rocha, M. M. (2012). Autoavaliação de competências e problemas de comportamento entre adolescentes brasileiros: Um estudo de validação do Inventário de Autoavaliação para Jovens (YSR/2001). Tese de Doutorado em Psicologia Clínica. Programa de Pós-Graduação em Psicologia Clínica, Instituto de Psicologia, Universidade de São Paulo.

Rockhill, C. M., Vander Stoep, A, McCauley, E. \& Keaton, W. J. (2009). Social competence and social support as mediators beween comorbid depressive and conduct problems and functional outcomes in middle school children. Journal of Adolescence, $32(3), 535-553$.
Silva, L. A. M. (2004). Sociabilidade violenta: Por uma interpretação da criminalidade contemporânea no Brasil urbano. Sociedade e Estudo, 19, 53-81.

Silveira, J. M., Silvares, E. F. M. \& Marton, S. A. (2003). Programas preventivos de comportamentos antisociais: dificuldades na pesquisa e implementação. Estudos de Psicologia (PUCCAMP), 20(3), 59-67.

Walker, H. M. \& Severson, H. H. (2002). Developmental prevention on at-risk outcomes for vulnerable antisocial children and youth. In K. L. Lane, F. M. Gresham \& T. E. O'Shaughnessy (Orgs.), Children with or at risk for emotional and behavioral disorders, (pp. 175-194). Boston: Allyn \& Bacon.

Williams, L. C. A. (2004). Violência e suas representações. In G. C. Solfa (Org.), Gerando cidadania: Reflexões, propostas e construções práticas sobre direitos da criança e do adolescente, (pp. 133-145). São Carlos: Rima. 
Annex A

Range of normative scores, item example and Alpha coefficient for each of the scores of YSR and IHSA-Del-Prette

\begin{tabular}{|c|c|c|c|c|}
\hline \multirow[b]{2}{*}{ Scale } & \multirow[b]{2}{*}{$\begin{array}{l}\text { Range of } \\
\text { scores }\end{array}$} & \multirow[b]{2}{*}{ Item example } & \multicolumn{2}{|c|}{ Alpha Coefficient } \\
\hline & & & $\begin{array}{c}\text { PEM } \\
(\mathrm{N}=24)\end{array}$ & $\begin{array}{c}\text { CLIN } \\
(\mathrm{N}=28)\end{array}$ \\
\hline YSR Anxious/Depressed & $0-26$ & I worry a lot & 0.637 & 0.754 \\
\hline YSR Withdrawn/Depressed & $0-16$ & I unhappy, sad, or depressed & 0.590 & 0.678 \\
\hline YSR Somatic Complaints & $0-20$ & I feel overtired without a good reason & 0.680 & 0.326 \\
\hline YSR Social Problems & $0-22$ & I get teased a lot & 0.711 & 0.750 \\
\hline YSR Thought Problems & $0-24$ & I can't get my mind off certain thoughts & 0.757 & 0.548 \\
\hline YSR Attention Problems & $0-18$ & $\begin{array}{l}\text { I have trouble concentrating or paying } \\
\text { attention }\end{array}$ & 0.623 & 0.668 \\
\hline YSR Rule Breaking Behavior & $0-30$ & I break rules at home, school, or elsewhere & 0.730 & 0.710 \\
\hline YSR Aggressive Behavior & $0-34$ & I threaten to hurt people & 0.850 & 0.871 \\
\hline YSR Internalizing Problems & $0-62$ & $\begin{array}{l}\text { (Composed by the scores of Anxious/ } \\
\text { Depressed, Withdrawn/Depressed and Somatic } \\
\text { Complaints) }\end{array}$ & 0.764 & 0.827 \\
\hline YSR Externalizing Problems & $0-64$ & $\begin{array}{l}\text { (Composed by the scores of Rule Breaking } \\
\text { Behavior and Aggressive Behavior) }\end{array}$ & 0.872 & 0.877 \\
\hline YSR Total Problems & $0-210$ & $\begin{array}{l}\text { Composed by all scores of all YSR problem } \\
\text { items) }\end{array}$ & 0.941 & 0.922 \\
\hline YSR Activities & $0-15$ & $\begin{array}{l}\text { Please list your favorite hobbies, activities, and } \\
\text { games, other than sports }\end{array}$ & 0.032 & 0.742 \\
\hline YSR Social & $0-14$ & $\begin{array}{l}\text { About how many times a week do you do } \\
\text { things with any friends outside of regular school } \\
\text { hours? }\end{array}$ & -0.050 & 0.119 \\
\hline YSR Total Competences & $0-32$ & $\begin{array}{l}\text { (Composed by the scores of Activities, Social } \\
\text { and School) }\end{array}$ & 0.266 & 0.774 \\
\hline YSR Positive Qualities & $0-32$ & I try to help other people when I can. & 0.759 & Q \\
\hline $\begin{array}{l}\text { IHSA Total Frequency } \\
\text { IHSA Total Difficulty }\end{array}$ & $\begin{array}{c}19-146 \\
5-132\end{array}$ & & $\begin{array}{l}0.890 \\
0.878\end{array}$ & $\begin{array}{l}0.925 \\
0.889\end{array}$ \\
\hline $\begin{array}{l}\text { F1 Empathy } \\
\text { D1 Empathy }\end{array}$ & $\begin{array}{l}4-40 \\
0-38\end{array}$ & $\begin{array}{l}\text { When I notice that a colleague is in trouble, I } \\
\text { offer my support. }\end{array}$ & $\begin{array}{l}0.778 \\
0.819\end{array}$ & $\begin{array}{l}0.886 \\
0.827\end{array}$ \\
\hline $\begin{array}{l}\text { F2 Self-Control } \\
\text { D2 Self-Control }\end{array}$ & $\begin{array}{l}2-32 \\
0-32\end{array}$ & I react calmly when things don't go as I wish. & $\begin{array}{l}0.718 \\
0.696\end{array}$ & $\begin{array}{l}0.719 \\
0.766\end{array}$ \\
\hline $\begin{array}{l}\text { F3 Civility } \\
\text { D3 Civility }\end{array}$ & $\begin{array}{l}1-24 \\
0-24\end{array}$ & $\begin{array}{l}\text { When I'm leaving a place, I say goodbye to } \\
\text { everyone. }\end{array}$ & $\begin{array}{l}0.653 \\
0.788\end{array}$ & $\begin{array}{l}0.831 \\
0.894\end{array}$ \\
\hline $\begin{array}{l}\text { F4 Assertiveness } \\
\text { D4 Assertiveness }\end{array}$ & $\begin{array}{l}3-28 \\
0-28\end{array}$ & $\begin{array}{l}\text { When someone request something that I think } \\
\text { is abusive (excessive or unfair), I refuse. }\end{array}$ & $\begin{array}{l}0.707 \\
0.628\end{array}$ & $\begin{array}{l}0.730 \\
0.631\end{array}$ \\
\hline $\begin{array}{l}\text { F5 Affective Approach } \\
\text { D5 Affective Approach }\end{array}$ & $\begin{array}{l}0-24 \\
0-22\end{array}$ & $\begin{array}{l}\text { When I want to date someone, I tell him/her at } \\
\text { the first chance }\end{array}$ & $\begin{array}{l}0.689 \\
0.730\end{array}$ & $\begin{array}{l}0.714 \\
0.776\end{array}$ \\
\hline $\begin{array}{l}\text { F6 Social Adroitness } \\
\text { D6 Social Adroitness }\end{array}$ & $\begin{array}{l}0-20 \\
0-19\end{array}$ & $\begin{array}{l}\text { At school or work, I make oral presentations } \\
\text { when requested }\end{array}$ & $\begin{array}{l}0.419 \\
0.473\end{array}$ & $\begin{array}{l}0.724 \\
0.725\end{array}$ \\
\hline
\end{tabular}

Source: own Work. 
